\title{
Physicochemical characterization and antioxidant capacity of pitanga fruits (Eugenia uniflora L.)
}

\author{
Caracterização fisico-química e capacidade antioxidante de pitangas (Eugenia uniflora L.)
}

\author{
Milena BAGETTI ${ }^{1}$, Elizete Maria Pesamosca FACCO ${ }^{1}$, Jaqueline PICCOLO ${ }^{1}$, Gabriela Elisa HIRSCH ${ }^{1}$, \\ Delia RODRIGUEZ-AMAYA², Cintia Nanci KOBORI², Márcia VIZZOTTO ${ }^{3}$ Tatiana EMANUELLI
}

\begin{abstract}
This study was carried out to obtain more information about the physicochemical properties, composition, and antioxidant activity of pitanga fruits (Eugenia uniflora L.), particularly fruits from the State of Rio Grande do Sul, Brazil. Pitanga with different flesh colors (purple, red, and orange) from tree selections cultivated at Embrapa Clima Temperado (RS-Brazil) were analyzed. Only slight differences were observed in the quality parameters and in the proximate and fatty acid compositions among the fruits studied. The extracts from purple-fleshed pitanga had the highest total phenolic and anthocyanin contents along with the highest antioxidant capacity. The antioxidant capacity (DPPH and FRAP assays) of methanolic pitanga extracts was highly correlated with the total phenolic content, but in ethanolic extracts, the anthocyanin content was correlated only with the FRAP antioxidant capacity. Orange fleshed pitanga had higher $\beta$-cryptoxanthin and $\beta$-carotene levels than those of the red fruit, which had higher lycopene content. The results indicate that the purple-fleshed pitanga, cultivated in Rio Grande do Sul, is a rich source of phenolic compounds and has high antioxidant capacity. The red and orange-fleshed pitanga, on the other hand, are rich sources of carotenoids.
\end{abstract}

Keywords: sugars; insaturated fatty acids; $\beta$-cryptoxanthin; lycopene; $\beta$-carotene.

\section{Resumo}

Este estudo foi realizado para obter mais informações sobre as propriedades físico-químicas, composição e atividade antioxidante de frutos de pitanga (Eugenia uniflora L.), especialmente os do Rio Grande do Sul (Brasil). Foram comparadas pitangas com diferentes colorações de polpa (roxa, vermelha e laranja) de seleções cultivadas na Embrapa Clima Temperado (RS-Brasil). Foram observadas pequenas diferenças nos parâmetros de qualidade e na composição centesimal e de ácidos graxos entre as frutas com diferentes colorações de polpa. Os extratos de pitanga roxa apresentaram maiores conteúdos totais de fenólicos e de antocianinas, bem como, a maior capacidade antioxidante. A capacidade antioxidante (valores de DPPH e FRAP) dos extratos metanólicos de pitanga apresentou alta correlação com o conteúdo de fenólicos totais, mas nos extratos etanólicos, o conteúdo de antocianinas correlacionou-se apenas com a capacidade antioxidante avaliada pelo método de FRAP. A pitanga de cor laranja apresentou maiores teores de $\beta$-criptoxantina e $\beta$-caroteno, enquanto que a de cor vermelha continha alto teor de licopeno. Os resultados indicam que a pitanga de cor roxa, cultivada no Rio Grande do Sul, é uma fonte rica de compostos fenólicos e possui alta capacidade antioxidante. As de cor vermelha e laranja, por outro lado, são fontes ricas de carotenoides.

Palavras-chave: açúcares; ácidos graxos insaturados; $\beta$-criptoxantina; licopeno; $\beta$-caroteno.

\section{Introduction}

It is widely known, from epidemiological studies, that the consumption of fruits and vegetables imparts many health benefits, especially reduced risk of chronic diseases, such as cancer, cardiovascular disease, and stroke (BLOCK; PATTERSON; SUBAR, 1992; DILLARD; GERMAN, 2000; PRIOR; CAO, 2000; KAUR; KAPOOR, 2001). Fruits and vegetables contain different antioxidant compounds, such as vitamin $\mathrm{C}$, vitamin E, and carotenoids. These phytochemicals may protect the human body against reactive oxygen and nitrogen species (DIPLOCK et al., 1998). Reactive oxygen species (ROS) are produced naturally in mammalian systems as a result of oxidative metabolism. However, excessive ROS production may damage cell membranes and DNA causing cancerous mutations. Moreover, the oxidation of low-density lipoprotein is a major factor in the pathogenesis of heart disease (RAHMAN; ADCOCK, 2006).

Vitamins and carotenoids are not the sole compounds that contribute to the antioxidant activity of fruits and vegetables.

Recebido para publicação em 27/2/2009

Aceito para publicação em 22/8/2009 (004080)

${ }^{2}$ Programa de Pós-graduação em Ciência e Tecnologia de Alimentos, Núcleo Integrado de Desenvolvimento em Análises Laboratoriais - NIDAL,

Departamento de Tecnologia e Ciência dos Alimentos, Centro de Ciências Rurais, Universidade Federal de Santa Maria - UFSM,

Camobi, CEP 97105-900, Santa Maria - RS, Brasil, E-mail: tatiemanuelli@smail.ufsm.br

${ }^{2}$ Departamento de Ciência de Alimentos, Faculdade de Engenharia de Alimentos, Universidade Estadual de Campinas - UNICAMP,

CP 6121, CEP 13083-970, Campinas - SP, Brasil

${ }_{3}^{3}$ Embrapa Clima Temperado, Rod. BR 392, Km 78, CP 403, CEP 96010-971, Pelotas - RS, Brasil

${ }^{*}$ A quem a correspondência deve ser enviada 
Polyphenolic compounds such as flavonoids also contribute to the beneficial effects of this group of foods (BORS et al., 1990). Polyphenolic compounds have shown antiallergenic, antiviral, antibacterial, antifungal, antitumor, and antihemorragic activities (PIETTA, 2000).

Eugenia uniflora L. is a widely distributed tree in South American countries, mainly in Brazil, Argentina, Uruguay, and Paraguay (CONSOLINI; SARUBBIO, 2002). Its leaves are used in popular medicine as infusion in the treatment of fever, rheumatism, stomach diseases, disorders of the digestive tract, hypertension, yellow fever, and gout. It may also reduce weight, blood pressure, and serve as a diuretic (ADEBAJO; OLOKI; ALADESANMI, 1989). Pitanga fruits, also known as Brazilian cherry or Suriname cherry, contain various volatile compounds that are also found in the essential oil of pitanga leaves (WEYERSTAHL et al., 1988; OLIVEIRA et al., 2006). Like the leaves, pitanga fruits may also have health benefits. In the Brazilian food industry, pitanga fruits have mostly been used to produce juice and frozen pulp. Pulp production has high economic potential because the product has consumer appeal and high concentrations of antioxidant compounds, such as anthocyanins, flavonols, and carotenoids (LIMA; MÉLO; LIMA, 2002).

Carotenoids are known to have various biological functions, such as vitamin A activity and prevention of cataract, age-related macular degeneration, cancer, and cardiovascular diseases (KRIS-ETHERTON et al., 2002; TAPIERO; TOWNSEND; TEW, 2004; KRINSKY; JOHNSON, 2005; STAHL; SIES, 2005). However, the carotenoid composition of pitanga fruits is variable. Lycopene is the major carotenoid in pitanga fruits cultivated in the following states: São Paulo, Pernambuco, and Paraná (Brazil), but other carotenoids have been found in different proportions depending on the geographic origin of the fruits (CAVALCANTE; RODRIGUEZ-AMAYA, 1992; AZEVEDO-MELEIRO; RODRIGUEZ-AMAYA, 2004; PORCU; RODRIGUEZ-AMAYA, 2008). Climate was found to influence the carotenoid composition of this fruit. The mean lycopene content of ripe pitanga fruits from Pernambuco $\left(73 \mu \mathrm{g} . \mathrm{g}^{-1}\right)$ was slightly higher than that of Campinas, São Paulo $\left(71 \mu \mathrm{g} . \mathrm{g}^{-1}\right)$, which was much higher than that of Medianeira, Paraná $\left(14 \mu \mathrm{g} \cdot \mathrm{g}^{-1}\right)$. As for $\beta$-crytoxanthin and rubixanthin, the levels were much higher in fruits from Pernambuco (47 and $23 \mu \mathrm{g} . \mathrm{g}^{-1}$, respectively) than those from São Paulo (12 and $9 \mu \mathrm{g} . \mathrm{g}^{-1}$, respectively) and Paraná (13 and $12 \mu \mathrm{g} \cdot \mathrm{g}^{-1}$, respectively). In addition to carotenoids, environmental factors can influence other components of fruits such as the phenolics (ROBARDS; ANTOLOVICH, 1997; AHERNE; O’BRIEN, 2002). However, these data are lacking for pitanga fruits, and no data have been found for pitanga from the Southern region of Brazil.

Knowledge of the proximate composition and the contents of bioactive compounds in different fruit varieties may be useful for genetic improvement programs to select the varieties with higher nutritional value. Thus, the objective of this work was to evaluate the physicochemical characteristics of pitanga fruits produced in the State of Rio Grande do Sul and to determine the antioxidant capacity of flesh extracts. We compared pitanga fruits with different flesh colors (purple, red, and orange). The fruits evaluated were from tree selections cultivated at Embrapa Clima Temperado (RS-Brazil) and have been studied to yield cultivars adapted to the Southern region of Brazil.

\section{Materials and methods}

\subsection{Samples}

Samples of purple, red and orange-fleshed breeding lines of pitanga fruits (Eugenia uniflora L.) were harvested at Embrapa Clima Temperado (Rio Grande of Sul, Brazil) in the years 2007 and 2008. Each sample was a mixture of completely ripe fruits from various plant selections with the same flesh color. Three independent lots were collected, frozen at $-18{ }^{\circ} \mathrm{C}$, and transported to the Federal University of Santa Maria. Fruits were thawed and the flesh (edible portions) was manually separated from seeds and homogenized in a blender. The samples were immediately analyzed for the carotenoids composition or stored at $-18{ }^{\circ} \mathrm{C}$ until required for other assays.

\subsection{Determination of quality parameters}

The parameters of quality evaluated were $\mathrm{pH}$, total soluble solids, and acidity. These parameters were evaluated according to AOAC (ASSOCIATION..., 1995).

\subsection{Determination of proximate composition}

Except for fat, the analyses were carried out according to AOAC (ASSOCIATION..., 1995). Moisture was determined as the weight loss after 24 hours at $60^{\circ} \mathrm{C}$ in a vacuum oven (method 925.09/17). Ash content was determined at $550{ }^{\circ} \mathrm{C}$ (method 923.03). Protein content $(\mathrm{N} \times 6.25)$ was determined by the microkjeldahl procedure (method 960.2). Fat was extracted using chloroform and methanol as described by Bligh and Dyer (1959); the extract was used for the determination of the fat content and fatty acid profile. To prevent lipid oxidation during and after extraction, $0.02 \%$ butyl hydroxyl toluene was added to the chloroform solution used.

\subsection{Determination of fatty acid composition}

Aliquots $(2-3 \mathrm{~mL})$ of the chloroform-lipid extract were evaporated at $50{ }^{\circ} \mathrm{C}$ using a vaccum pump. Fat was saponified and methylated with methanolic sulfuric acid solution, as described by Hartman and Lago (1973). The methylated samples were analyzed using an Agilent Technologies (HP 6890) gas chromatograph with flame ionization detector. The methylated fatty acids were separated in a capillary column DB-23 (50\% cyanopropyl-methylpolysiloxane; $60 \mathrm{~m} \times 0.25 \mathrm{~mm} \times 0.25 \mu \mathrm{m}$; Agilent Technologies). The oven temperature was held at $140^{\circ} \mathrm{C}$ for 5 minutes, increased to $240{ }^{\circ} \mathrm{C}$ at a rate of $4{ }^{\circ} \mathrm{C} /$ minute, and held at the latter temperature for 5 minutes. The injector port and detector temperature were adjusted at $250^{\circ} \mathrm{C}$. The samples $(1 \mu \mathrm{L})$ were injected in a split mode (split ratio 1:50). Nitrogen was used as carrier gas at a flow rate of $0.6 \mathrm{~mL} /$ minute. 


\subsection{Determination of phenolic content}

The extraction of phenolic compounds was performed using the method of Escarpa and González (2001) with some modifications, as described by Pellegrini et al. (2007). This method allows a quantitative extraction of the main polyphenolic classes: hydroxybenzoic acids, hydroxycinnamic acids, and flavonoids. The homogenized sample (4 g) was extracted in an ultrasonic bath at room temperature in the absence of light with an aqueous solution consisting of $800 \mathrm{~mL}$ methanol and $50 \mathrm{~mL}$ formic acid per liter. The samples were sequentially extracted with $6 \mathrm{~mL}$ of solvent for 1 hour and $6 \mathrm{~mL}$ for 30 minutes and $3 \mathrm{~mL}$ for 30 minutes. After each extraction, the extracts were filtered under vacuum. The combined filtrate was brought to a final volume of $25 \mathrm{~mL}$ with the solvent and stored at $-18{ }^{\circ} \mathrm{C}$ until required for analysis.

Total phenolic content was determined using the method of Singleton and Rossi (1965). An aliquot of $0.1 \mathrm{~mL}$ pulp extract was mixed with $2.5 \mathrm{~mL} 0.25 \mathrm{~N}$ Folin-Ciocalteu reagent. After 5 minutes, $2 \mathrm{~mL} 1 \mathrm{~N} \mathrm{Na}_{2} \mathrm{CO}_{3}$ was added. The absorbance was determined at $740 \mathrm{~nm}$ after 1 hour in the dark. Gallic acid was used as a standard for the calibration curve. The amount of total phenolic compounds was calculated and expressed as mg gallic acid. $100 \mathrm{~g}^{-1}$ sample.

\subsection{Determination of anthocyanin content}

The extraction of anthocyanins was performed as described by Lees and Francis (1972). The pulp was homogenized in the extracting solvent containing 95\% ethanol and $1.5 \mathrm{~N} \mathrm{HCl} 85: 15 \mathrm{v} / \mathrm{v}$. The proportion sample/extracting solvent was $0.8 \mathrm{~g} \cdot \mathrm{mL}^{-1}$. The sample was stored for 12 hours at $4{ }^{\circ} \mathrm{C}$, filtered under vacuum, and the residue was exhaustingly washed with the extracting solvent for complete removal of pigments. The filtrates were collected in a volumetric flask, brought to $50 \mathrm{~mL}$ with the extracting solvent, and left to stand in the absence of light for 2 hours at room temperature; absorbance was measured at $535 \mathrm{~nm}$.

\subsection{Diphenyl-2-picrylhydrazyl (DPPH) radical scavenging assay}

A solution of DPPH was used for the determination of the antioxidant activity of extracts according to Brand-Williams, Cuvelier and Berset (1995). DPPH solution was previously diluted until $1.10 \pm 0.02$ absorbance at $515 \mathrm{~nm}$ was obtained. The extract $(0.05 \mathrm{~mL})$ was mixed with $1.9 \mathrm{~mL}$ diluted methanolic DPPH solution. The antiradical power of the different extracts was determined by measuring the decrease of DPPH absorbance after 24 hours in the dark against a blank. Trolox was used as a standard for the calibration curve and the results were expressed as mmol trolox equivalents. $100 \mathrm{~g}^{-1}$ sample.

\subsection{Ferric-reducing antioxidant power (FRAP) assay}

The method of Benzie and Strain (1996) was used for the FRAP assays. Ferric-2,4,6-trypyridyl-s-triazine (TPTZ) solution was prepared by mixing $2.5 \mathrm{~mL} 10 \mathrm{mM}$ TPTZ solution in $40 \mathrm{mM} \mathrm{HCl}, 2.5 \mathrm{~mL} 20 \mathrm{mM} \mathrm{FeCl}_{3} \cdot 6 \mathrm{H}_{2} \mathrm{O}$ and $25 \mathrm{~mL} 0.3 \mathrm{M}$ acetate buffer at $\mathrm{pH}$ 3.6. The sample $(40 \mu \mathrm{L})$ was mixed with $1.2 \mathrm{~mL}$ of ferric-TPTZ reagent and incubated at $37^{\circ} \mathrm{C}$ for 15 minutes. The absorbance of the colored complex formed with $\mathrm{Fe}^{+2}$ and TPTZ was taken at $593 \mathrm{~nm}$. Trolox was used as a standard for the calibration curve and the results were expressed as mmol trolox equivalents. $100 \mathrm{~g}^{-1}$ sample.

\subsection{Carotenoid analysis}

Carotenoid analyses were performed at the Carotenoid Laboratory of the University of Campinas-UNICAMP. Carotenoids were extracted with cold acetone, partitioned to petroleum ether:ethyl ether (2:1), saponified overnight with $10 \% \mathrm{KOH}$ in methanol with $0.1 \%$ butyl hydroxy toluene, washed with water, and concentrated in a rotary evaporator (RODRIGUEZ-AMAYA, 1999). Saponification was necessary to hydrolyze carotenoid esters. HPLC-DAD analyses were carried out on a Waters separation module (model 2690) equipped with a quaternary pump, a four-channel in-line vacuum degasser, and an autosampler injector, controlled by Millenium 2010 workstation. A monomeric C18 Spherisorb ODS 2, $3 \mu \mathrm{m}$, 4.6 i.d. $\times 150 \mathrm{~mm}$ column was used for all samples. After drying the extract with nitrogen gas, the carotenoids were dissolved in $2 \mathrm{~mL}$ acetone, filtered through a $0.22 \mu \mathrm{m}$ PTFE syringe filter (Millipore), and $10 \mu \mathrm{L}$ were injected. The mobile phase consisted of acetonitrile (containing 0.05\% triethylamine), methanol, and ethyl acetate. A concave gradient was employed, from 95:5:0 to 60:20:20 in 20 minutes, maintaining the last proportion until the end of the run. Reequilibration took 15 minutes (time of set up), and the flow rate was $0.5 \mathrm{~mL} /$ minute. For quantification, calibration curves were constructed for $\beta$-cryptoxanthin, $\beta$-carotene and lycopene with five concentration levels, each in triplicate. The carotenoid quantification was performed by the comparison of the peak area of the sample with that of the standard, injected daily. The identification of carotenoids was performed according to Rodriguez-Amaya (1999) by the combined use of chromatographic behavior, UV-visible spectra obtained with a photodiode array detector, and co-chromatography with authentic carotenoid standards. The results were expressed as $\mu \mathrm{g} \cdot \mathrm{g}^{-1}$ fresh sample.

\subsection{Statistical analysis}

All measurements were carried out in triplicate. The results were analyzed by one-way analysis of variance (ANOVA) followed by Tukey's test when appropriate. Carotenoid data were analyzed by the Student's $T$ test. The results were considered significant when $\mathrm{p}<0.05$. Statistical analyses were carried out using Statistica 6.0 (Copyright Sta Soft, Inc 1984-2001).

\section{Results and discussion}

The quality parameters of purple, red, and orange-fleshed pitanga fruits are shown in Table 1. Purple-fleshed pitanga had higher $\mathrm{pH}$, total soluble solids, and acidity than those of red and orange-fleshed fruits $(\mathrm{p}<0.05)$. Orange and red-fleshed pitanga had similar $\mathrm{pH}$ and total soluble solids, but the red-fleshed fruit had higher acidity than that of the orange-fleshed pitanga $(\mathrm{p}<0.05)$. The $\mathrm{pH}$ of red-fleshed pitanga is close to that 
Table 1. Quality parameters of purple, red, and orange-fleshed pitanga (Eugenia uniflora L.).

\begin{tabular}{lcccc}
\hline \multicolumn{1}{c}{ Samples } & $\mathrm{pH}$ & TSS ( ${ }^{\circ}$ Brix $)$ & $\begin{array}{c}\text { Acidity } \\
\text { (\% citric acid) }\end{array}$ & Yield (\%) \\
\hline Legal limits (Brazil) & $2.5-3.4$ & $>6.0$ & $>0.92$ & - \\
Purple & $3.38 \pm 0.02^{\mathrm{a}}$ & $13.8 \pm 0.2^{\mathrm{a}}$ & $1.87 \pm 0.09^{\mathrm{a}}$ & 7.4 \\
Red & $2.88 \pm 0.06^{\mathrm{b}}$ & $11.5 \pm 0.0^{\mathrm{b}}$ & $1.67 \pm 0.01^{\mathrm{b}}$ & 76.8 \\
Orange & $3.01 \pm 0.11^{\mathrm{b}}$ & $11.8 \pm 0.2^{\mathrm{b}}$ & $1.63 \pm 0.02^{\mathrm{c}}$ & 77.2 \\
\hline
\end{tabular}

Results are means \pm standard deviations $(n=3)$. Means with different letters within the same column are statistically different $(\mathrm{p}<0.05)$. TSS: total soluble solids.

previously reported for commercial frozen pulp of pitanga (2.89) (SALGADO; GUERRA; MELO FILHO, 1999). However, the total soluble solids content obtained in the present study is higher than that found for frozen pulp (SALGADO; GUERRA; MELO FILHO, 1999). The quality characteristics of the purple, red, and orange pitanga fruits analyzed are within the legal limits established for frozen fruit pulp in Brazil (BRASIL, 2000 ) indicating that the maturation stage of the pitanga fruits evaluated was suitable for processing into frozen pulp.

The moisture content varied significantly among the pitanga samples with different flesh color: orange $>$ red $>$ purple (Table 2). Although the moisture content of all samples was lower than previously reported for pitanga (88\%) (UNIVERSIDADE..., 2006) and for commercial frozen pitanga pulps (90.5\%) (SALGADO; GUERRA; MELO FILHO, 1999), it is still considered high. This characteristic is common among fruits from the Myrtaceae family, which are classified as succulent (GEMTCHÜJNICOV, 1976).

Purple-fleshed pitanga had the highest ash content followed by orange and red- fleshed pitanga $(\mathrm{p}<0.05)$. The ash content of all samples was higher than previously reported for pitanga (0.4\%) (UNIVERSIDADE..., 2006), which demonstrates the good concentration of minerals in the samples analyzed. No significant difference was observed in the protein, fat, and carbohydrate contents, which were higher than previously reported for pitanga $(0.9,0.2$ and $10.2 \%$, respectively) (UNIVERSIDADE..., 2006). As observed for other fruits, these data show that carbohydrates were the major contributors to the caloric value of pitanga with minor contribution from protein and fat.

The predominant fatty acids in all pitanga samples were palmitic (C16:0), followed by oleic (C18:1n9c) and linoleic acids (C18:2n6) (Table 3). No studies were found on the fatty acid composition of pitanga or other fruits from the Myrtaceae family.

Pitanga fruits had a high proportion of unsaturated fatty acids (49-56\%), 20-25\% monounsaturated and 29-32\% polyunsaturated fatty acids. No significant difference was found in palmitic and linolenic (C18:3n3) acids among the samples (Table 3). Oleic acid was found at a higher proportion in purple pitanga, followed by red and orange pitangas, whereas palmitoleic acid $(\mathrm{C} 16: 1 \mathrm{n} 7 \mathrm{c})$ was higher in orange and red fruits than in purple pitanga. Linoleic acid was found at a higher proportion in purple and red fruits than in orange pitanga.
The phenolic compounds influence the fruit quality contributing both to their sensory and health-promoting properties (SCALZO et al., 2005). The phenolic content and antioxidant capacity of the extracts of the three fruits are shown in Table 4. The methanolic extract from purple-fleshed pitanga had higher phenolic content than those of the red and orange-fleshed fruits $(\mathrm{p}<0.05$; Table 4$)$, possibly due to the presence of anthocyanins. According to Reynerston et al. (2008), who analyzed and quantified several antioxidants and antiinflammatory flavonols, phenolic acids, and anthocyanins from 14 underutilized tropical Myrtaceae fruits, the anthocyanins are the most abundant compounds among those quantified and are responsible for the bright color of those fruits.

The phenolic content of purple fleshed pitanga was higher than previously reported for purple ( $325 \mathrm{mg}$ catechin. $100 \mathrm{~g}^{-1}$ f.w.) and red (257 mg catechin. $100 \mathrm{~g} \mathrm{~g}^{-1}$ f.w.) mature pitanga from Pernambuco (LIMA; MÉLO; LIMA, 2002) and for cambuci (Campomanesia phea Berg.), which also belongs to the Myrtaceae family (246 $\mathrm{mg}$ gallic acid.100 $\mathrm{g}^{-1}$ f.w.) (GENOVESE et al., 2008). Although red and orange-fleshed pitanga had lower phenolic content when compared to the purple samples, its phenolic content is higher than that of araçá (Psidium guineensis Sw.), which is also a Myrtaceae fruit (129 mg gallic acid. $100 \mathrm{~g}^{-1}$ f.w.) (GENOVESE et al., 2008). Moreover, the phenolic content of pitanga fruits was higher than that of mulberry, grape, and açai pulps (119, 117 and $137 \mathrm{mg}$ gallic acid. $100 \mathrm{~g}^{-1}$ f.w., respectively) (KUSKOSKI et al., 2006). However, the phenolic content of pitanga fruits was 5 to 10 fold lower than that of pitanga seeds (BAGETTI et al., 2009).

DPPH and FRAP assays are indicated as simple and rapid methods for assessing the antioxidant capacity of fruits and vegetables. The antioxidant capacity of pitanga fruits, determined by the FRAP and DPPH assays, was expressed as equivalents of the standard antioxidant trolox, which is a hydrosoluble analog of vitamin E. Both the ferric-reducing power and the DPPH radical scavenging capacity were higher for the methanolic extracts from purple fleshed color pitanga than for the red and orange fruits $(\mathrm{p}<0.05)$ (Table 4). Several authors demonstrated a strong positive correlation between phenolic content and the antioxidant capacity of fruits (VISON et al., 1998; KAUR; KAPPOR, 2001; ABIDILLE et al., 2005; PINTO; LAJOLO; GENOVESE, 2007). We also found a highly positive correlation between the content of phenolics and DPPH $\left(\mathrm{r}^{2}=0.987 ; \mathrm{p}<0.05\right)$ and FRAP $\left(\mathrm{r}^{2}=0.983 ; \mathrm{p}<0.05\right)$ values. This suggests that phenolics are the major responsible 
Table 2. Proximate composition (\%) of purple, red, and orange-fleshed pitanga (Eugenia uniflora L.).

\begin{tabular}{lccccc}
\hline Samples & Moisture & Ash & Protein & Fat & Carbohydrate $^{\star}$ \\
\hline Purple & $81.2 \pm 0.0^{\mathrm{c}}$ & $2.4 \pm 0.1^{\mathrm{a}}$ & $1.2 \pm 0.5^{\mathrm{a}}$ & $0.4 \pm 0.0^{\mathrm{a}}$ & $14.8 \pm 0.4^{\mathrm{a}}$ \\
Red & $83.9 \pm 0.0^{\mathrm{b}}$ & $1.1 \pm 0.0^{\mathrm{c}}$ & $1.4 \pm 0.0^{\mathrm{a}}$ & $0.4 \pm 0.0^{\mathrm{a}}$ & $13.2 \pm 0.0^{\mathrm{a}}$ \\
Orange & $84.7 \pm 0.2^{\mathrm{a}}$ & $1.7 \pm 0.8^{\mathrm{b}}$ & $1.1 \pm 0.0^{\mathrm{a}}$ & $0.5 \pm 0.0^{\mathrm{a}}$ & $12.9 \pm 1.1^{\mathrm{a}}$ \\
\hline
\end{tabular}

Results are means \pm standard deviations $(\mathrm{n}=3)$. Means with different letters within the same column are statistically different $(\mathrm{p}<0.05) .{ }^{*}$ Calculated by difference.

Table 3. Fatty acid composition (\% of total fatty acids) of purple, red, and orange-fleshed pitanga (Eugenia uniflora L.).

\begin{tabular}{lcrr}
\hline Fatty acids & Purple & \multicolumn{1}{c}{ Red } & Orange \\
\hline C16:0 & $34.6 \pm 1.0^{\mathrm{a}}$ & $33.4 \pm 0.2^{\mathrm{a}}$ & $34.7 \pm 0.2^{\mathrm{a}}$ \\
C16:1n7c & $2.7 \pm 0.1^{\mathrm{b}}$ & $3.2 \pm 0.1^{\mathrm{a}}$ & $3.0 \pm 0.1^{\mathrm{a}}$ \\
C18:1n9c & $22.4 \pm 0.1^{\mathrm{a}}$ & $21.1 \pm 0.2^{\mathrm{b}}$ & $17.6 \pm 0.2^{\mathrm{c}}$ \\
C18:2n6c & $18.9 \pm 0.2^{\mathrm{a}}$ & $18.8 \pm 0.4^{\mathrm{a}}$ & $17.0 \pm 0.3^{\mathrm{b}}$ \\
C18:3n3 & $12.8 \pm 0.6^{\mathrm{a}}$ & $13.1 \pm 0.2^{\mathrm{a}}$ & $12.4 \pm 0.3^{\mathrm{a}}$ \\
NI & $8.6 \pm 0.6$ & $7.8 \pm 0.7$ & $7.9 \pm 0.1$ \\
\hline
\end{tabular}

Results are means \pm standard deviations $(\mathrm{n}=3)$. Means with different letters within the same row are statistically different $(\mathrm{p}<0.05)$. C12:0, C14:0, C14:1n5, C18:0, C18:1n9t, C18:2n6t, C20:1n9, C20:4n6, C20:5n3, C22:0, C22:5n3 and C22:6n3 were not detected. NI: unidentified compounds.

Table 4. Phenolic content and antioxidant capacity of methanolic extracts from purple, red, and orange-fleshed pitanga (Eugenia uniflora L.).

\begin{tabular}{|c|c|c|c|}
\hline Samples & $\begin{array}{c}\text { Phenolic content } \\
\left(\mathrm{mg} \text { gallic acid. } 100 \mathrm{~g}^{-1}\right)\end{array}$ & $\begin{array}{c}\text { DPPH } \\
\left(\mathrm{mmol} \text { trolox. } 100 \mathrm{~g}^{-1}\right)\end{array}$ & $\begin{array}{c}\text { FRAP } \\
\left(\mathrm{mmol} \text { trolox.100 } \mathrm{g}^{-1}\right)\end{array}$ \\
\hline Purple & $463 \pm 16^{a}$ & $3.1 \pm 0.7^{\mathrm{a}}$ & $3.1 \pm 0.6^{\mathrm{a}}$ \\
\hline Red & $210 \pm 3^{\mathrm{b}}$ & $1.4 \pm 0.1^{\mathrm{b}}$ & $1.4 \pm 0.3^{\mathrm{b}}$ \\
\hline Orange & $179 \pm 5^{\mathrm{b}}$ & $1.4 \pm 0.0^{\mathrm{b}}$ & $1.1 \pm 0.1^{\mathrm{b}}$ \\
\hline
\end{tabular}

Results are expressed as gallic acid or trolox equivalents per $100 \mathrm{~g}$ of fresh pulp used to prepare the extract and are the means \pm standard deviations $(\mathrm{n}=3$ ); DPPH: 1,1-diphenyl-2-picrylhydrazyl; FRAP: ferric reducing antioxidant power. Different letters within the same column indicate significant differences ( $<<0.05$ ).

compounds for the antioxidant capacity of the methanolic extracts from pitanga samples.

Among phenolic compounds, the anthocyanin content has been suggested as an important criterion for predicting a high antioxidant activity of fruits since anthocyanin-rich samples usually show the highest antioxidant capacity (HASSIMOTTO; GENOVESE; LAJOLO, 2005). Therefore, we extracted anthocyanins from pitanga pulp using an ethanolic solution. The results of anthocyanin content and antioxidant capacity of these extracts are shown in Table 5. As with the phenolic content, the ethanolic extract from purple-fleshed pitanga had the highest anthocyanin content followed by the extracts from red and orange samples $(p<0.05)$. The anthocyanin contents of purple and red fleshed pitanga are higher than those of frozen pulps of blackberry (Morus nigra) (41.8 mg.100 g-1), grape (Vitis vinifera) (30.9 mg.100 g $\mathrm{g}^{-1}$ ), and açaí fruit (Euterpe oleracea) $\left(22.8 \mathrm{mg} .100 \mathrm{~g}^{-1}\right)$ although lower than those of methanolic (578 mg. $100 \mathrm{~g} \mathrm{~g}^{-1}$ ) and ethanolic extracts (596 mg.100 g $\mathrm{g}^{-1}$ ) from baguaçu (Eugenia umbelliflora Berg.) (KUSKOSKI et al., 2006), which is from the same genus as pitanga.

The DPPH radical scavenging capacity was not different among the ethanolic extracts from pitanga samples. However, the ferric-reducing power of the ethanolic extract from purple-fleshed pitanga was higher than those of the other samples. Moreover, the anthocyanin content had a positive correlation with FRAP values $\left(r^{2}=0.938 ; p<0.05\right)$, but showed no relationship with DPPH values (data not shown). The antioxidant capacity (DPPH and FRAP values) of anthocyanin extracts (Table 5) was (2.6 to 29 fold) higher than that of the phenolic extracts (Table 4).

Two possible explanations can be given for the discrepancy noted above. Firstly, the two assays are based on different principles. While the FRAP assay measures the ferric reducing capacity of antioxidants, the DPPH assay measures the ability of antioxidants to scavenge the DPPH radical. Secondly, the conditions used to obtain the anthocyanin extract like the successive washing until complete extraction of pigments or the polarity of the extracting solution might have led to the extraction of more compounds with greater antioxidant capacity. In agreement with this proposal, Beekwilder et al. (2005) found that anthocyanins, ellagitanins, and proanthocyanidins are the major compounds responsible for the antioxidant capacity of raspberry samples.

The results demonstrated that pitanga is a rich source of anthocyanins when compared with other fruits, and that purple pitanga, in general, had the highest antioxidant capacity when compared to the other fleshed color samples.

$\alpha$-Carotene, $\beta$-carotene, $\beta$-cryptoxanthin, lycopene, lutein, and zeaxanthin are the most studied and are considered 
Table 5. Total anthocyanin content and antioxidant capacity of ethanolic extracts from purple, red, and orange-fleshed pitanga (Eugenia uniflora L.).

\begin{tabular}{|c|c|c|c|}
\hline Samples & $\begin{array}{l}\text { Anthocyanin content } \\
\left(\mathrm{mg} .100 \mathrm{~g}^{-1}\right)\end{array}$ & $\begin{array}{c}\text { DPPH } \\
\left(\mathrm{mmol} \text { trolox. } 100 \mathrm{~g}^{-1}\right)\end{array}$ & $\begin{array}{c}\text { FRAP } \\
\left(\mathrm{mmol} \text { trolox. } 100 \mathrm{~g}^{-1}\right)\end{array}$ \\
\hline Purple & $136 \pm 6^{a}$ & $37 \pm 2^{a}$ & $8.2 \pm 0.4^{\mathrm{a}}$ \\
\hline Red & $69 \pm 3^{\mathrm{b}}$ & $41 \pm 0^{\mathrm{a}}$ & $4.4 \pm 0.3^{b}$ \\
\hline Orange & $25 \pm 1^{\mathrm{c}}$ & $41 \pm 0^{\mathrm{a}}$ & $4.2 \pm 0.4^{\mathrm{b}}$ \\
\hline
\end{tabular}

Results are expressed as anthocyanin content or trolox equivalents per $100 \mathrm{~g}$ of fresh pulp used to prepare the extract and are the means \pm standard deviations ( $\mathrm{n}=3$ ); DPPH: 1,1-diphenyl-2-picrylhydrazyl; FRAP: ferric reducing antioxidant power. Different letters within the same column indicate significant differences ( $\mathrm{p}<0.05$ ).

Table 6. Carotenoid composition ( $\mu$ g.g $\mathrm{g}^{-1}$ ) of red and orange-fleshed pitanga (Eugenia uniflora L.).

\begin{tabular}{lccc}
\hline Samples & $\beta$-Cryptoxanthin & Lycopene & $\beta$-Carotene \\
\hline Red & $16 \pm 2$ & $166 \pm 7$ & $2.9 \pm 0.8$ \\
Orange & $34 \pm 7^{*}$ & $151 \pm 30$ & $5.1 \pm 0.8^{*}$ \\
\hline
\end{tabular}

Results are the mean \pm standard deviation $(\mathrm{n}=3) .{ }^{\star}$ Different from red samples (Student's $T$ test, $\left.\mathrm{p}<0.05\right)$.

the most important carotenoids in terms of human health (RODRIGUEZ-AMAYA, 1999). Among them, lycopene has remarkably high antioxidant efficiency (DI MASCIO; KAISER; SIES, 1989) and has been suggested to protect humans against degenerative disorders (CLINTON, 1998). The carotenoids found in red and orange pitanga samples in the present study were lycopene, $\beta$-cryptoxanthin, and $\beta$-carotene (Table 6). Rubixanthin was also detected, but as a minor carotenoid.

The lycopene contents of the red and orange samples analyzed in this work were much higher than those of pitanga samples from São Paulo $\left(71 \mu \mathrm{g} \cdot \mathrm{g}^{-1}\right)$ and Paraná $\left(14 \mu \mathrm{g} \cdot \mathrm{g}^{-1}\right)$ (PORCU; RODRIGUEZ-AMAYA, 2008). Moreover, the pitanga samples from the state of Rio Grande do Sul had higher lycopene content than that of the fruits considered as important sources of lycopene such as watermelon $\left(36 \mu \mathrm{g} \cdot \mathrm{g}^{-1}\right)$ (NIIZU; RODRIGUEZAMAYA, 2003), guava (53 $\left.\mu \mathrm{g} \cdot \mathrm{g}^{-1}\right)$ (PADULA; RODRIGUEZAMAYA, 1986), and papaya (cv. Formosa, $26 \mu \mathrm{g} . \mathrm{g}^{-1}$ ) (KIMURA; RODRIGUEZ-AMAYA; YOKOYAMA, 1991). Orange-fleshed pitanga had higher $\beta$-carotene and $\beta$-cryptoxanthin content than red pitanga $(\mathrm{p}<0.05)$. The $\beta$-carotene and $\beta$-cryptoxanthin contents of red pitanga obtained in the present study are similar to those previously reported for red pitanga from São Paulo and Paraná (PORCU; RODRIGUEZ-AMAYA, 2008).

\section{Conclusions}

Only slight differences were observed in the quality parameters and in the proximate and fatty acid compositions among the fruits with different flesh color. Although the red-fleshed pitanga had higher lycopene content, the orange-fleshed pitanga had higher $\beta$-cryptoxanthin and $\beta$-carotene concentrations than the red fruit. The extracts from purple-fleshed pitanga had the highest total phenolic and anthocyanin content along with the highest antioxidant capacity. The antioxidant capacity determined by the DPPH and FRAP assays of the methanolic pitanga extracts was highly correlated with the total phenolic content, but in ethanolic extracts, the anthocyanin content was correlated only to FRAP antioxidant capacity. The results showed that purple fleshed pitanga cultivated in the Rio Grande do Sul is a rich source of phenolics, whereas the orange and red-fleshed pitanga fruits are rich sources of carotenoids.

\section{Acknowledgements}

The authors thank Embrapa Clima Temperado of Pelotas-RS for the samples of pitanga and Carlos Rubini Junior for the work in the gas chromatograph. Tatiana Emanuelli and Delia Rodriguez-Amaya are the recipients of $\mathrm{CNPq}$ research fellowships. Milena Bagetti is the recipient of a CAPES Master Degree fellowship. Jaqueline Piccolo is the recipient of a $\mathrm{CNPq}$ Master Degree fellowship. This study was supported by Edital Casadinhos (FAPERGS/CAPES) to PPGCTA-UFSM.

\section{References}

ABIDILLE, M. D. H. et al. Antioxidant activity of the extracts from Dillenia indica fruits. Food Chemistry, v. 90, n. 4, p. 891-896, 2005.

ADEBAJO, A. C.; OLOKI, K. J.; ALADESANMI, A. Antimicrobial activity of the leaf extract of Eugenia uniflora. Journal of Phytotherapy Resource, v. 3, n. 6, p. 258-259, 1989.

AHERNE, S. A.; O'BRIEN, N. M. Dietary flavonols: chemistry, food content, and metabolism. Nutrition, v. 18, n. 1, p. 75-81, 2002.

ASSOCIATION OF OFFICIAL ANALYTICAL CHEMISTS - AOAC. Official methods of analysis of the Association of the Official Analytical Chemists. $16^{\text {th }}$ ed. Arlington, Virginia: AOAC, 1995.

AZEVEDO-MELEIRO, C. H.; RODRIGUEZ-AMAYA, D. B. Confirmation of the identity of the carotenoids of tropical fruits by HPLC-DAD and HPLC-MS. Journal of Food Composition and Analysis, v. 17, n. 3-4, p. 385-396, 2004.

BAGETTI, M. et al. Antioxidant capacity and composition of pitanga seeds. Ciência Rural, v. 39, n. 8, p. 204-2510, 2009.

BEEKWILDER, J. et al. Antioxidant in raspberry: on-line analysis links antioxidant activity to a diversity of individual metabolites. Journal of Agricultural and Food Chemistry, v. 53, n. 9, p. 3313-3320, 2005.

BENZIE, F. F. I.; STRAIN, J. J. The ferric reducing ability of plasma (FRAP) as a measure of "antioxidant power": the FRAP assay. Analytical Biochemistry, v. 239, n. 1, p. 70-76, 1996.

BLIGH, E. G.; DYER, W. J. A rapid method of total lipid extraction and purification. Journal of Biochemistry and Physiology, v. 37, n. 8, p. 911-917, 1959. 
BLOCK, G.; PATTERSON, B.; SUBAR, A. Fruits, vegetables and cancer prevention: a review of the epidemiological evidence. Nutrition and Cancer, v. 18, n. 1, p.1-29, 1992.

BORS, W. et al. Flavonoids as antioxidants: determination of radical scavenging efficiencies. Methods in Enzymology, v. 186, p. 343-355, 1990.

BRAND-WILLIAMS, W.; CUVELIER, M. E.; BERSET, C. Use of a free radical method to evaluated antioxidant activity. LebensmittelWissenschaft und-Technologie, v. 28, n. 1, p. 25-30, 1995.

BRASIL. Instrução Normativa, $n^{\circ} 1$, de 7 de janeiro de 2000. Regulamento técnico geral para fixação dos padrões de identidade e qualidade para polpa de fruta. Diário Oficial da República Federativa do Brasil, Brasília, DF, 10 jan. 2000. Seção 1, p. 54. Disponível em: <http://extranet.agricultura.gov.br/sislegisconsulta/ consultarLegislacao.do? operacao=visualizar\&id=7777>. Acesso em: 18 dez. 2008.

CAVAlCANTE, M. L.; RODRIGUEZ-AMAYA, D. B. Carotenoid composition of the tropical fruits Eugenia uniflora and Malpighia glabra. In: CHARALAMBOUS, G. (Ed.). Food Science and Human Nutrition. Amsterdam: Elsevier Science Publishers, 1992. p. 643-650.

CLINTON, S. K. Lycopene: chemistry, biology, and implications for human health and disease. Nutrition Reviews, v. 56, n. 2, p. 35-51, 1998.

CONSOLINI, A. E.; SARUBBIO, M. Pharmacological effects of Eugenia uniflora L. (Myrtaceae) aqueous extract on rat's heart. Journal of Ethnopharmacology, v. 81, n. 1, p. 57-63, 2002.

DI MASCIO, P.; KAISER, S.; SIES, H. Lycopene as the most efficient biological carotenoid singlet oxygen quencher. Archives of Biochemistry and Biophysics, v. 274, n. 2, p. 532-538, 1989.

DILLARD, C. J.; GERMAN, J. B. Phytochemicals: neutraceuticals and human health. Journal of the Science of Food and Agriculture, v. 80, n. 12, p. 1744-1756, 2000.

DIPLOCK, A. T. et al. Functional food sciences and defense against reactive oxidative species. British Journal of Nutrition, v. 80, n. 1, p. 77-112, 1998.

ESCARPA, A.; GONZALEZ, M. C. Approach to the content of total extractable phenolic compounds from different food samples by comparison of chromatographic and spectrophotometric methods. Analytica Chimica Acta, v. 427, n. 1, p. 119-127, 2001.

GEMTCHÜJNICOV, I. D. Manual de taxonomia vegetal: plantas de interesse econômico, agrícola, ornamentais e medicinais. São Paulo: Ceres, 1976. 368 p.

GENOVESE, M. I. et al. Bioactive compounds and antioxidant capacity of exotic fruits commercial frozen pulps from Brazil. Food Science and Technology International, v. 4, n. 3, p. 207-214, 2008.

HARTMAN, L.; LAGO, B. C. A rapid preparation of fatty methyl esters from lipids. Laboratory Practice, v. 22, n. 6, p. 475-477, 1973.

HASsimotTO, N. M. A.; GENOVESE, M. I.; LAJOlO, F. M. Antioxidant activity of dietary fruits, vegetables, and commercial frozen fruit pulps. Journal of Agricultural and Food Chemistry, v. 53, n. 8, p. 2928-2935, 2005.

KAUR, C.; KAPOOR, H. Antioxidants in fruits and vegetables - the millennium's health. International Journal of Food Science and Technology, v. 36, n. 7, p. 703-725, 2001.

KIMURA, M.; RODRIGUEZ-AMAYA, D. B.; YOKOYAMA S. M., Cultivar differences and geographic effects on the carotenoid composition and vitamin A value of papaya. LebensmittelWissenschaft und-Technologie, v. 24, n. 5, p. 415-418, 1991.

KRINSKY, N. I.; JOHNSON, E. J. Carotenoid actions and their relation to health and disease. Molecular Aspects of Medicine, v. 26, n. 6, p. 459-516, 2005.

KRIS-ETHERTON, P. M. et al. Bioactive compounds in foods: Their role in the prevention of cardiovascular disease and cancer. American Journal of Medicine, v. 113, n. 9, p. 71-88, 2002.

KUSKOSKI, M. E. et al. Frutas tropicais silvestres e polpas de frutas congeladas: atividade antioxidante, polifenóis e antocianinas. Ciência Rural, v. 36, n. 4, p. 1283-1287, 2006.

LEES, D. H.; FRANCIS, F. J. Standardization of pigment analyses in cranberries. Hortscience, v. 7, n. 1, p. 83-84, 1972.

LIMA, V. L. A. G.; MÉLO, E. A.; LIMA, D. E. S. Fenólicos e carotenóides totais em pitanga. Scientia Agricola, v. 59, n. 3, p. 447-450, 2002.

NIIZU, P. Y.; RODRIGUEZ-AMAYA, D. B. A melancia como fonte de licopeno. Revista do Instituto Adolfo Lutz, v. 62, n. 3, p. 195-199, 2003.

OLIVEIRA, A. L. et al. Volatile compounds from pitanga fruit (Eugenia uniflora L.). Food Chemistry, v. 99, n. 1, p. 1-5, 2006.

PADULA, M.; RODRIGUEZ-AMAYA, D. B. Characterization of the carotenoids and assessment of the vitamin A value of Brazilian guavas (Psidium guajava L.). Food Chemistry, v. 20, n. 1, p. 11-19, 1986.

PELLEGRINI, N. et al. Evaluation of antioxidant capacity of some fruit and vegetable foods: efficiency of extraction of a sequence of solvents. Journal of the Science of Food and Agriculture, v. 87, n. 1, p. 103-111, 2007.

PIETTA, P. G. Flavonoids as antioxidants. Journal of Natural Products, v. 63, n. 7, p. 1035-1042, 2000.

PINTO, M. S.; LAJOLO, F. M.; GENOVESE, M. I. Bioactive compounds and quantification of total ellagic acid in strawberries (Fragaria $\times$ ananassa Duch.). Food Chemistry, v. 107, n. 4, p. 1629-1635, 2007.

PORCU, O. M.; RODRIGUEZ-AMAYA, D. B. Variation in the carotenoid composition of the lycopene-rich Brazilian fruit Eugenia uniflora L. Plant Foods for Human Nutrition, v. 63, n. 4, p. 195-199, 2008.

PRIOR, R. L.; CAO, G. Antioxidant phytochemicals in fruits and vegetables: diet and health implications. Horticulture Science, v. 35, n. 4 , p. 588-592, 2000.

RAHMAN, I.; ADCOCK, I. M. Oxidative stress and redox regulation of lung inflammation in COPD. European Respiratory Journal, v. 28, n. 1, p. 219-242, 2006.

REYNERSTON, K. A. et al. Quantitative analysis of antiradical phenolic constituents from fourteen edible Myrtaceae fruits. Food Chemistry, v. 109, n. 4, p. 883-890, 2008.

ROBARDS, K.; ANTOLOVICH, M. Analytical chemistry of fruit bioflavonoids. Analyst, v. 122, p. 11R-34R, 1997.

RODRIGUEZ-AMAYA, D. B. A guide to carotenoid analysis in foods. Washington, D.C.: ILSI Press, 1999.

SALGADO, S. M.; GUERRA, N. B.; MELO FILHO, A. B. Frozen fruit pulps: Effects of the processing on dietary fiber contents. Brazilian Journal of Nutrition, v. 12, n. 3, p. 303-308, 1999.

SCALZO, J. et al. Plant genotype affects total antioxidant capacity and phenolic contents in fruit. Nutrition, v. 21, n. 2, p. 207-213, 2005. 
SINGLETON, V. L.; ROSSI Jr., J. A. Colorimetry of total phenolic with phosphomolybdic-phosphotungstic acid reagents. American Journal of Enology and Viticulture, v. 16, n. 3, p. 144-158, 1965.

STAHL, W.; SIES, H. Bioactivity and protective effects of natural carotenoids. Biochimica et Biophysica Acta, v. 1740, n. 2, p. 101-107, 2005.

TAPIERO, H.; TOWNSEND, D. M.; TEW, K. D. The role of carotenoids in the prevention of human pathologies. Biomedicine and Pharmacotherapy, v. 58, n. 2, p. 100-110, 2004.
UNIVERSIDADE DE CAMPINAS - UNICAMP. Tabela brasileira de composição de alimentos - TACO. 2. ed. Version II. Campinas: NEPA/UNICAMP, 2006. 113 p.

VISON, J. A. et al. Phenol antioxidant quantity and quality in foods: vegetables. Journal of Agricultural and Food Chemistry, v. 46, n. 9, p. 4113-4117, 1998.

WEYERSTAHL, P. et al. Volatile constituents of Eugenia uniflora leaf oil. Planta Médica, v. 54, n. 6, p. 546-549, 1988. 